International Journal of English Literature and Social Sciences
Vol-6, Issue-4; Jul-Aug, 2021
Journal Home Page Available: $\underline{\text { https://ijels.com/ }}$ Journal DOI: $10.22161 /$ ijels

Peer-Reviewed Journal

\title{
Powtoon Media: Can It Improve Student Achievement in Accounting?
}

\author{
Monica Hapsari Pambayun*, Siswandari, Cicilia Dyah Sulistyaningrum
}

Faculty of Teacher Training and Education, Sebelas Maret University, Indonesia

Received: 20 Jul 2021; Received in revised form: 15 Aug 2021; Accepted: 21 Aug 2021; Available online: 27 Aug 2021

(C)2021 The Author(s). Published by Infogain Publication. This is an open access article under the CC BY license

(https://creativecommons.org/licenses/by/4.0/).

\begin{abstract}
The world of education with all its challenges requires a teacher to be able to make students interpret learning materials more easily so that student learning achievement increases, one of which is through innovative learning media. The purpose of this research was to improve the learning achievement of students of tenth-grade Accounting and Finance at SMK Kristen Surakarta. The number of students in this class was 32 people who were all taken as subjects in this study. Classroom action research was adopted for this research with qualitative and quantitative data analysis techniques. Research data were collected through tests, observations, interviews, and documentation. Test the validity of the data used was content validity and triangulation. The success of the action is indicated if $75 \%$ of the students have a score > 76. It is concluded from this study that the powtoon media succeeded in increasing the learning achievement of students in grade tenth, Accounting, and Finance. This finding is evidenced by an increase in the proportion of students who score $>76$. The proportion of students who scored $>76$ in the pre-action was $56 \%$ which then increased to $72 \%$ in cycle I and $84 \%$ in cycle II.
\end{abstract}

Keywords - Powton Media, Learning Achievement.

\section{INTRODUCTION}

Learning is defined as a structured activity with a responsive approach to students to achieve progress and participation where a strong relationship occurs between students and parents as learning partners [1]. Learning is a dynamic and active process in the world of education that aims to develop an understanding of students' knowledge [2]. [3] further reveals that learning is a process of measuring, collecting, and reporting students which are intended to optimize understanding of the material in school. Learning activities have changed a lot along with the times which require teachers to apply innovative learning media so that students become more active in participating in learning [4]. The application of innovative media encourages students to take advantage of more approaches to learning so that their involvement will be more active, while also increasing competence, motivation, and confidence in their learning [5]
The phenomenon during the initial observations revealed that the learning achievement obtained by students was still relatively low, which was indicated by $56 \%$ of students who had scores below 76 which was the minimum learning mastery score (KKM). This is because there are still many students or more precisely 20 out of 32 students who do not focus on teaching and learning activities. Other phenomena that also occur include students who tend to be busy themselves and do not pay close attention to the subject matter explained by the teacher.

Based on some of these phenomena, it is known that the learning media applied by this SMK, especially in class $\mathrm{X}$ AKK basic banking subjects, may still be inappropriate and there are only a few updates. This is in line with [6] which states that all levels of education require renewal where higher education must always change and need a lot of innovation. Innovation is updating what already exists which gives birth to new ideas that aim to improve 
products, services, or processes [7]. [8] stated that innovation is a form of learning renewal process in which students participate in doing, using, and interacting to learn. [9] also emphasizes that innovation is a new idea, process, or method so that a new perception emerges that has been created by the innovator. Innovation in education has become a necessity as many people believe that the social and economic welfare of the country depends on the quality of education so that the human resources they have are of higher quality.[10].

The use of learning media cannot be done by simply choosing without knowing and considering the condition of the students. It was known that based on the observations that have been carried out, the absorption of the subject matter by students will be easier to use the media in the form of short illustrated videos. The use of creative media that is tailored to the teaching needs of students will attract students so that it leads to better teaching [11].

An application is needed in making this video that will make it easier for teachers to present it well. One application that is suitable as a medium for making learning videos accompanied by pictures is Powtoon. This is supported by [12] which states that the powtoon learning media is suitable to be applied as an interesting learning media as its use does not need to be installed because it can be accessed online on the web www.PowToon.com.

Powtoon learning media is a tool whose operation is similar to a powerpoint or pre-zi. Powtoon is a free presentation software application that can be given a narrative in it and uploaded to Youtube for anyone to access [13]. This media uses slides for writing which can be added with images and animations equipped with sound or music [14]. Powtoon is a cloud-based communication information technology tool that can be used by teachers and students to visualize animated presentations [15]. [16] also stated that by applying the powtoon learning media, users can add music, sounds, animations, and interesting themes as desired [17] also added that media powtoon has several types of theme choices with various types of videos, such as explainer videos, marketing videos, infographic videos, video ads. [18] further explained that unique cartoon characters and varied animation models presented in one display screen were applied through powtoon media. Another study conducted by [19] stated that some of the advantages of powtoon are that the message conveyed by the video is clear and easy to understand with attractive visuals so that it is not boring to watch. Based on this description, the purpose of this research is to obtain empirical evidence to improve student achievement in class $\mathrm{X}$ Accounting and Finance, SMK
Kristen 1 Surakarta through the application of powtoon media.

\section{RESEARCH METHODOLOGY}

This research took place at SMK Kristen 1 Surakarta intending to improve student achievement through the application of powtoon media. The research subjects were 32 students and were students of class X Accounting and Finance, consisting of 6 male students and 26 female students. The determination of the research class was based on the condition of class X Accounting and Finance who had low academic achievement.

Research information was obtained from three sources, namely the teacher of basic banking subjects for class $\mathrm{X}$ Accounting and Finance; events in this study, which are a series of student behavior in participating in teaching and learning activities; documents obtained from school archives, which contain student data and test results for basic banking subjects.

The data in this study were collected to determine the increase in student achievement consisting of a pre-test at the beginning of the first cycle which was carried out using a written test technique, where the final test was given in each cycle. Observation is done by observing, implementing, identifying, and analyzing the advantages and disadvantages of each cycle that takes place. Interviews with accounting teachers were conducted to strengthen the results of the research derived from the results of tests and observations obtained. The data validity test technique in this study used content validity and triangulation.

The data analysis technique, in this case, is in the form of quantitative and qualitative data analysis techniques. Analysis of quantitative data was done by calculating the average value of students and learning mastery. Critical analysis technique on the other hand aims to analyze qualitative data so that the weaknesses and strengths of student and teacher performance during the process of implementing the cycle can be identified. The indicator of success in learning achievement is determined from the increase in achievement in each cycle. The results are declared successful if the increase in the percentage of learning achievement is $75 \%$ of the total number of students has a score $>76$. The determination of success indicators in basic banking subjects is as follows: 
Table 1: Success Indicators

\begin{tabular}{lll}
\hline $\begin{array}{c}\text { Measured } \\
\text { Aspect }\end{array}$ & $\begin{array}{c}\text { The target } \\
\text { of Learning } \\
\text { Mastery } \\
\text { Percentage }\end{array}$ & \multicolumn{1}{c}{$\begin{array}{c}\text { How to Get } \\
\text { Percentage }\end{array}$} \\
\hline $\begin{array}{l}\text { Student } \\
\text { achievement }\end{array}$ & $75 \%$ & $\begin{array}{l}\text { Comparison between } \\
\text { the students who meet } \\
\text { the score above the } \\
\text { KKM with the total } \\
\text { number of students in } \\
\text { the class. }\end{array}$ \\
\hline
\end{tabular}

The research procedure was designed and divided into four steps. These steps include research preparation, research implementation, observation and interpretation, analysis, and reflection.

The research procedure is more concisely presented in the form of an image as follows:


\section{RESULT AND DISCUSSION}

\subsection{Result}

\subsubsection{Pre-action Data}

Based on observations on the implementation of learning that was carried out when the basic banking subjects for class X Accounting and Finance took place, several problems were found in its implementation. These problems include: student learning achievement is classified as low; lack of student focus during lessons and some students are busy themselves with other activities during lessons. Efforts to improve student learning achievement and improve the learning process begin by carrying out preliminary tests to determine students' abilities without looking at books or any sources related to basic banking subjects. The initial test given is in the form of an essay test consisting of 5 questions with deposit material where the time given to solve this question is 20 minutes. This material of time depost is given according to the agreement of the tutor and will be taught in each cycle. Christian Vocational School 1 Surakarta has set the Minimum Completeness Criteria for basic banking subjects of $>76$. Thus, students will be declared complete if they get a score of more than 76 .

The results obtained from the initial test are used as a reference for acting. The test results are presented in the distribution table of grade $\mathrm{X}$ Accounting and Finance students as follows:

Table 2: Score Distribution of Student in Grade X Accounting and Finance Students at the Pre-Action stage

\begin{tabular}{ccc}
\hline Score & Frequency & Information \\
\hline $91-100$ & 0 & Passed \\
$81-90$ & 18 & Passed \\
$76-80$ & 0 & Passed \\
$71-75$ & 1 & Not pass \\
$61-70$ & 8 & Not pass \\
$51-60$ & 3 & Not pass \\
$40-50$ & 2 & Not pass \\
\hline Total & 32 &
\end{tabular}

Based on the table, it can be seen the distribution of scores obtained by students of class X Accounting and Finance. To clarify the distribution of student scores that have been presented in the table, a graph of student scores is made which is presented in the following figure: 
Graph 1: Score Distribution of Student in Grade X Accounting and Finance Students at the Pre-Action stage

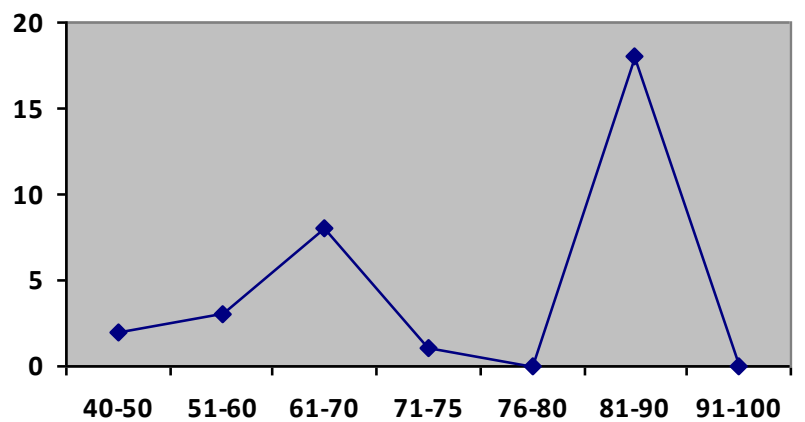

Based on the value distribution data presented in tables and figures, a learning mastery table can be made as follows:

Table 3: Learning mastery of Grade X Accounting and Finance Students at the Pre-Action Stage

\begin{tabular}{ccc}
\hline Category & Total students & Percentage \\
\hline Passed & 18 & $56 \%$ \\
Not pass & 14 & $44 \%$ \\
\hline Total & 32 & $100 \%$ \\
\hline
\end{tabular}

Referring to the results of the initial tests that have been obtained, it can be concluded that the level of mastery of student learning is still low. This is as shown by the learning mastery table where only $56 \%$ of the number of students who have a score more than the KKM, or only 18 students who are declared passed. In addition, the percentage level obtained was also found to have not met the established success indicators, $75 \%$ of the total number of students in the class. In other words, to achieve student learning mastery, there must be at least 24 students who are declared passed.

Knowing the results obtained, the efforts that can be made to improve student learning mastery are through the application of appropriate media in class X Accounting and Finance. The media referred to in this case is powtoon media whose application is expected to improve student learning achievement.

\subsubsection{Results of Actions at Cycle I}

The research process was carried out in two cycles consisting of two meetings in each cycle. Each cycle consists of four stages, namely: planning, implementing actions, observing and interpreting, analyzing, and reflecting on actions.

a. Action Planning
Activities in action planning include: making learning implementation plans, determining learning resources, making learning media, determining implementation times. After formulating the implementation of the action, the researcher and the teacher together made evaluation questions and research instruments. The questions formulated were 4 questions in the form of essays. Evaluation questions were used to determine the success of the actions taken.

\section{b. Action Execution}

Cycle I activities were divided into two meetings. The material given in the first cycle is time deposits and types of time deposits. The explanation of the material is carried out in the classroom using powtoon media.

\section{c. Observation and Interpretation}

Observations were made to observe students' cognitive abilities and to find out how much success was obtained in cycle I. This stage went according to plan, although it was still not optimal because there were students who depended on their friends so that only a few students were serious in the process of learning and teaching activities, while the rest were busy doing other things. Based on the evaluation test scores conducted at the second meeting, it was found that the students' scores had increased, but had not yet reached the target of success. The percentage of the number of students who completed was $56 \%$ in the preaction then increased to $72 \%$ in the first cycle. These results indicate that the results obtained are still below the success indicators that have been set. The results of the tests carried out in the first cycle are presented in the distribution table of students' scores as follows:

Table 4: Score Distribution of Grade X Students in Accounting and Finance at Cycle I

\begin{tabular}{ccc}
\hline Score & Frequency & Information \\
\hline $91-100$ & 4 & Passed \\
$81-90$ & 19 & Passed \\
$76-80$ & 0 & Passed \\
$71-75$ & 5 & Not pass \\
$61-70$ & 3 & Not pass \\
$51-60$ & 1 & Not pass \\
\hline Total & 32 & \\
\hline
\end{tabular}

To clarify the distribution of student scores in the table, the graph of student scores is presented as follows:

Graph 2: Score Distribution of Grade X Students in Accounting and Finance at Cycle I 


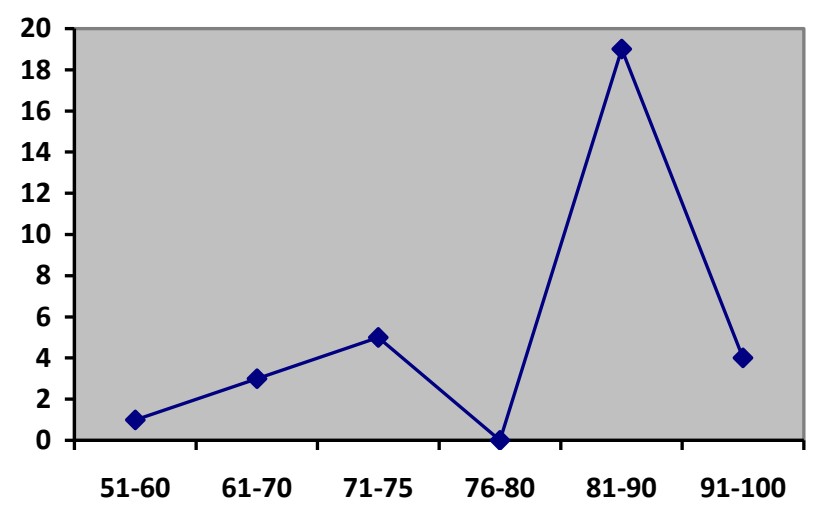

Based on the value distribution data, a learning mastery table can be made as follows:

Table 5: Learning Mastery of Grade X Accounting and Finance Students in Cycle 1

\begin{tabular}{ccc}
\hline Category & Total Students & Percentage \\
\hline Passed & 23 & $72 \%$ \\
Not pass & 9 & $28 \%$ \\
\hline Total & 32 & $100 \%$ \\
\hline
\end{tabular}

\section{d. Reflection}

Referring to the results of observations and interpretations in cycle I, it is reflected that there has been an increase in learning achievement obtained after the action has been taken, although the results still show that the minimum completeness has been determined. Some of the deficiencies observed in cycle 1 are as follows:

1) Lack of cooperation during discussions as the researchers saw that some students depend on friends, while other students were busy with things off the topic of the subject matter.

2) The teacher is not optimal in presenting the subject matter, namely the display of learning media that is too long so that students do not have the leeway to discuss.

Observations in the implementation of the first cycle concluded that the application of powtoon media could improve student achievement. However, improvements are still needed in its implementation because the results obtained have not yet reached the indicators of success. In other words, cycle II needs to be done.

Reflections to improve cycle 1 are:

1) The teacher gives warnings to students who are still busy with other activities through mentoring students one by one.
2) Teachers should use time more optimally in preparing powtoon media before learning begins so that students have more free time to discuss.

\subsubsection{Cycle II Action Results}

The action research was carried out in two cycles which in each cycle were divided into two meetings. Each cycle consists of four steps, namely research preparation, research implementation, observation and interpretation, analysis, and reflection on actions.

a. Action Planning

In general, the action planning steps in the second cycle are almost the same as the first cycle. However, the second cycle planning is added to the improvement in the cycle. Activities in action planning include: making learning implementation plans, determining learning resources, making learning media, determining implementation times. After formulating the implementation of the action, the researcher and the teacher together make evaluation questions and research instruments. The questions formulated are 5 questions in the form of essays. Evaluation questions are used to determine the success of the actions taken.

b. Action Execution

Cycle II activities were carried out in two meetings. The material given in cycle II was deposit interest services including its calculation and implementation of powtoon media. The first meeting was focused on explaining deposit material and calculations, then for the second meeting, an evaluation test of deposit interest service materials was carried out, including the calculation. The explanation of the material took place in the classroom using powtoon media.

\section{c. Observation and Interpretation}

Observations of learning achievement from cycle I to cycle II were carried out through observations aimed at knowing the increase in learning achievement in each cycle and the percentage of success obtained in cycle II. The implementation of this stage has been carried out according to the plan which is equipped with improvements. Improvements were carried out by preparing equipment to display Powtoon media before learning begins and giving warnings to students who are still busy with other activities. Based on the evaluation test scores, it was found an increase in student achievement. The percentage of students who pass in the first cycle was $72 \%$. This percentage increased to $84 \%$ in cycle II. These results indicate that the percentage of student achievement mastery has met the predetermined success indicators. The results of the tests carried out in cycle II are presented in the distribution table of students' scores as follows: 
Table 6: Score Distribution of Grade X Students in Accounting and Finance at Cycle II

\begin{tabular}{ccc}
\hline Score & Frequency & Information \\
\hline $91-100$ & 7 & Passed \\
$81-90$ & 18 & Passed \\
$76-80$ & 2 & Passed \\
$71-75$ & 4 & Not pass \\
$61-70$ & 1 & Not pass \\
\hline Total & 32 &
\end{tabular}

To clarify the distribution of student scores in the table, the graph of student scores is presented as follows:

Graph 3: Score Distribution of Grade X Students in Accounting and Finance at Cycle I



Based on the value distribution data, a learning mastery table can be made as follows:

Table 7: Study Completion of Grade X Students in Accounting and Finance at Cycle II

\begin{tabular}{ccc}
\hline Category & Total Students & Percentage \\
\hline Passed & 27 & $84 \%$ \\
Not pass & 5 & $16 \%$ \\
\hline Total & 32 & $100 \%$
\end{tabular}

\section{d. Reflection}

Based on the results of observations and interpretations of cycle II, it can be reflected that there is an increase in learning achievement obtained so that the class average value has met the minimum learning mastery that has been determined, and $84 \%$ of the total number of students were declared passed because they have a value above the KKM, which is 76 . With the achievement of the indicators that have been set, this research can be ended in cycle II. For students who have not been able to achieve the minimum mastery learning, teachers need to provide remedial and special assignments to improve student grades. Based on the results of the implementation of the first cycle which continued with the second cycle, this study concluded that the use of powtoon media can improve student achievement in class X Accounting and Finance in basic banking subjects.

\subsubsection{Comparison of Cycle Results}

The implementation of action research from cycle I to cycle II indicated that the application of powtoon media succeeded in improving student achievement, especially in basic banking subjects. This result comparison table is made to clarify the improvement from pre-action, cycle I, and cycle II as follows:

Table 8: Store Comparison of Grade X Students in Accounting and Finance

\begin{tabular}{lcccccc}
\hline 1 & 2 & 3 & 4 & 5 & 6 & 7 \\
\hline $75 \%$ & Pre-Action & 14 & 18 & 32 & $56 \%$ & \\
\hline $75 \%$ & Cycle I & 9 & 23 & 32 & $72 \%$ & $16 \%$ \\
\hline $75 \%$ & Cycle II & 5 & 27 & 32 & $84 \%$ & $12 \%$ \\
\hline
\end{tabular}

Where:

1.: Success Indicator

2.: Action

3.: Students who did not pass

4.: Students who passed

5.: Number of Students

6.: Level of Completeness

7.: Improvement

From the comparison table of student scores, it is known that an increase in student achievement occurs in each cycle. There were only 18 students who passed the preaction or only $56 \%$ who were declared passed. The results of student achievement also increased in the second cycle, the indicators set by the school had not been achieved. The increase is represented by a percentage of $16 \%$, from $56 \%$ to $72 \%$ or 23 students are declared complete. The percentage increase in cycle II was $12 \%$, from $72 \%$ to $84 \%$, or 27 students were declared complete. Thus, based on the results of the second cycle, the research can be ended. These results are then presented in a comparison graph to clarify the comparison of completeness results for each action as follows: 
Graph 4: Comparison of Cycle Results

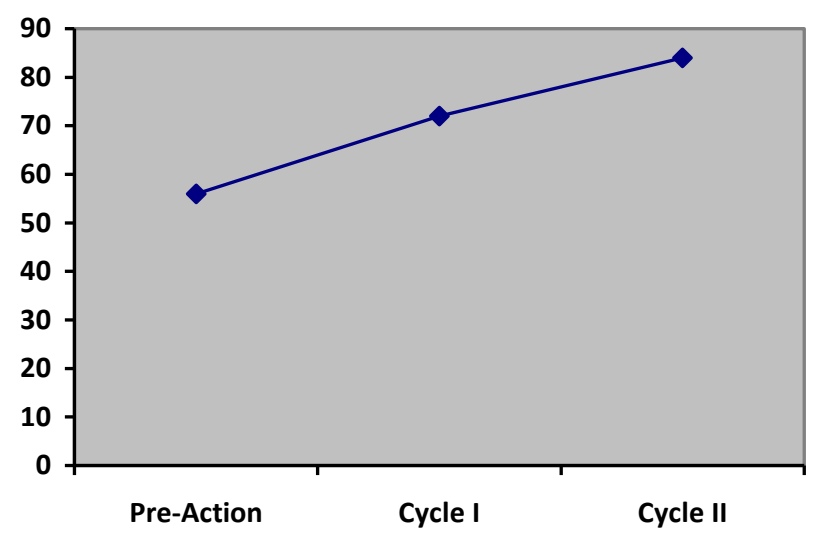

\subsection{Discussion}

This study aims to improve student achievement in class $\mathrm{X}$ Accounting and Finance at SMK Kristen 1 Surakarta in basic banking subjects. Based on the observed phenomena, several obstacles were found in each action in the preaction activity. These obstacles include the low learning achievement of students, the lack of students' creative abilities, and the use of innovative learning media. Low student achievement is evidenced by the results of the preaction test which revealed that only 18 students have passed or scored above the KKM, while the other 14 students have not passed.

Innovative and interactive media are needed to deal with existing problems so that student learning achievements that are classified as low can be improved. This is following the statement of [20] that innovative learning media can improve students' understanding and learning achievement and make it easier for students to learn independently. Other research also states that learning media will help to further develop the quality of student learning and participation in learning and cognitive processes [21]. Learning media that uses technology are known to be able to encourage students to achieve learning achievements in learning activities and form quality activities [22].

The implementation of this research is divided into 2 cycles which in each cycle consists of 2 meetings. Powtoon media has been applied in cycle I, but some obstacles are still found, precisely at the preparation stage for making media, where teachers have difficulty creating a powtoon media, account so researchers need to help. On the other hand, teachers have been able to create illustrations and animations using powtoon media. There were no significant obstacles found in the first cycle of activities. However, the researcher observed that the teacher was still not able to divide the time well in preparing the presentation of the media, thereby reducing the time for student learning discussions. Researchers also found students who were still busy themselves with activities off the topic of discussion during learning.

The action of the first cycle has shown the enthusiasm of students to take part in learning and increase learning achievement. The results of the action in the first cycle are better than the results of the pre-action although the results obtained still do not meet the established success indicators. In the pre-action activities, as many as 14 students still did not complete. This number decreased after the implementation of the first cycle to 9 students. Factors that influence the improvement of student learning outcomes in the first cycle is the application of powtoon media. The use of powtoon media is proven to help students to understand the material that has been given by the teacher.

The benefits of powtoon media in teaching and learning activities are in line with the statement [18] which reveals that the application of powtoon media can help to achieve a more optimal understanding by providing easy-toremember material. This media is also more attractive for students to watch presentations because of the fun animations presented. [16] also mentions that the benefits of using powtoon media are to overcome monotonous media and the limitations of teaching media with language that is easily understood by students. The increase in learning achievement in the first cycle indicates the beginning of the successful application of the powtoon media.

The research was continued to cycle II to correct deficiencies in cycle I and improve student achievement. In the implementation of cycle II, no obstacles were found in teaching and learning activities because the teacher seemed to be more expert in operating the powtoon media and was able to manage time well so that students had enough time to discuss. For students who are still busy or talking off-topic, the teacher has determined a class leader who is in charge of reprimanding the student. The discussion went quite well which was shown by good cooperation by the students where they helped each other when there were students who still had difficulty understanding the material. Success is also indicated by an increase in student achievement in cycle I. In cycle II, students who have scores below the KKM are reduced to 5 students. This indicates an increase in the percentage of mastery learning. The percentage of students who passed in cycle II increased by $12 \%$, namely from $72 \%$ in the first cycle to $84 \%$. Learning situations that prioritize positive cooperation will have a good impact on the development of students' abilities and psychology. This is following the statement [15] which revealed that a more positive 
relationship and better psychological adjustment are needed to produce higher learning achievement with a pleasant learning atmosphere. Based on the results of the two activities in cycle I and cycle II, it is concluded that powtoon media can improve student achievement in class $\mathrm{X}$ Accounting and Finance at SMK Kristen 1 Surakarta in basic banking subjects.

\section{CONCLUSION}

Based on the data analysis and discussion that the author has done in the previous chapter, it can be concluded that the application of powtoon media has succeeded in increasing the learning achievement of class X accounting and finance students at SMK Kristen 1 Surakarta. Improved learning achievement is indicated by an increase in the percentage of students who have scores above the Minimum Completeness Criteria (KKM), namely 76.

a. Pre-Action

At this stage, the level of mastery learning achieved by students of class X Accounting and Finance is 56\%. The total number of students in this class is 32 . In other words, only 18 students were declared complete, while the other 14 students were declared incomplete.

\section{b. Cycle I}

The level of mastery learning achieved by students of class $\mathrm{X}$ Accounting and Finance at this stage has increased, from $56 \%$ in the pre-action to $72 \%$. Referring to the total number of students as many as 32, then 23 students were declared passed, and the remaining 9 students were declared did not pass.

\section{c. Siklus II}

At this stage, the level of mastery learning achieved by students of class $\mathrm{X}$ Accounting and Finance increased from $72 \%$ in the first cycle to $84 \%$. In other words, $84 \%$ of the 32 students indicated that 27 students were declared passed, while the remaining 5 students were declared did not pass.

The application of powtoon media based on the findings of this study was declared successful in improving the learning achievement of class X Accounting and Finance students at SMK Kristen 1 Surakarta. The findings lead to the conclusion that the results of this study can be used as material for consideration by teachers in the learning process whose characteristics are relatively the same as the material or subject that the author uses in this study.

\section{REFERENCES}

[1] Darling-Hammond, L., Flook, L., Cook-Harvey, C., Barron, B., \& Osher, D. (2020). Implications for the educational practice of the science of learning and development. Applied Developmental Science, 24(2), 97140. https://doi.org/10.1080/10888691.2018.1537791

[2] Runesson, U. (2016). Pedagogical and learning theories in the lesson and learning studies - revisited. International Journal for Lesson and Learning Studies, 5(4), 295-299. https://doi.org/10.1108/IJLLS-07-2016-0017

[3] Li, K. C., \& Wong, B. T. M. (2020). Trends of learning analytics in STE(A)M education: a review of case studies. Interactive Technology and Smart Education, 17(3), 323335. https://doi.org/10.1108/ITSE-11-2019-0073

[4] Roehl, A., Reddy, S. L., \& Shannon, G. J. (2013). The Flipped Classroom: An Opportunity To Engage Millennial Students Through Active Learning Strategies. Journal of Family \& Consumer Sciences, 105(2), 44-49. https://doi.org/10.14307/jfcs105.2.12

[5] Chandra, P., Tomitsch, M., \& Large, M. (2020). Innovation education programs: a review of definitions, pedagogy, frameworks and evaluation measures. European Journal of Innovation Management, 24(4), 1268-1291. https://doi.org/10.1108/EJIM-02-2020-0043

[6] Serdyukov, P. (2017). Innovation in education: what works, what doesn't, and what to do about it? Journal of Research in Innovative Teaching \& Learning, 10(1), 4-33. https://doi.org/10.1108/jrit-10-2016-0007

[7] Swayne, N., Selznick, B., McCarthy, S., \& Fisher, K. A. (2019). Uncoupling innovation and entrepreneurship to improve undergraduate education. Journal of Small Business and Enterprise Development, 26(6-7), 783-796. https://doi.org/10.1108/JSBED-04-2019-0122

[8] Ludwig, P. M., Nagel, J. K., \& Lewis, E. J. (2017). Student learning outcomes from a pilot medical innovations course with nursing, engineering, and biology undergraduate students. International Journal of STEM Education, 4(1). https://doi.org/10.1186/s40594-017-0095-y

[9] Alquraan, F. (2008). Education, Business and Society: Contemporary Middle Eastern Issues. Education, Business and Society: Contemporary Middle Eastern Issues, 1(3). https://doi.org/10.1108/ebs.2008.34901caa.002

[10] Cornali, F. (2012). Effectiveness and Efficiency of Educational Measures: Evaluation Practices, Indicators, and Rhetoric. Sociology Mind, 02(03), 255-260. https://doi.org/10.4236/sm.2012.23034

[11] Aravopoulou, E., Stone, M., \& Weinzierl, L. (2017). Modernising the curriculum and pedagogy - to be or not to be? using film and online video to engage students and enhance learning. International Journal of Higher Education Management, 4(1), 1-18.

[12] Nurdiansyah, E., Faisal, E. El, \& Sulkipani, S. (2018). Pengembangan media pembelajaran berbasis PowToon pada perkuliahan Pendidikan Kewarganegaraan. Jurnal Civics: Media Kajian Kewarganegaraan, 15(1), 1-8. https://doi.org/10.21831/jc.v15i1.16875

[13] Forbes, C. (2014). Free Web-based tools for information literacy instruction. Library Hi Tech News, 31(10), 1-5. https://doi.org/10.1108/LHTN-10-2014-0093

[14] Aksoy, G. (2012). The Effects of Animation Technique on the 7th Grade Science and Technology Course. Creative 
Education, 303(03), 304-308. https://doi.org/10.4236/ce.2012.33048

[15] Wu, Y. J., Yuan, C. H., \& Pan, C. I. (2018). Entrepreneurship education: An experimental study with information and communication technology. Sustainability (Switzerland), 10(3), 1-13. https://doi.org/10.3390/su10030691

[16] Bakri, F., Rodhiyah, A., Nurindrasari, M., Pratiwi, S., \& Muliyati, D. (2020). The Design of Physics Learning Video as Joyful-Based Learning Media Enrichment by Powtoon. Journal of Physics: Conference Series, 1491(1). https://doi.org/10.1088/1742-6596/1491/1/012061

[17] Bower, M. (2017). Design of Web 2.0 Enhanced Learning. Design of Technology-Enhanced Learning, 159-217. https://doi.org/10.1108/978-1-78714-182-720171009

[18] Pais, M. H. R., Nogués, F. P., \& Muñoz, B. R. (2017). Incorporating powtoon as a learning activity into a course on technological innovations as didactic resources for pedagogy programs. International Journal of Emerging Technologies in Learning, 12(6), 120-131. https://doi.org/10.3991/ijet.v12i06.7025

[19] Günaydin, S., \& Karamete, A. (2016). Material development to raise awareness of using smart boards: An example design and development research. European Journal of Contemporary Education, 15(1), 114-122. https://doi.org/10.13187/ejced.2016.15.114

[20] Simaremare, S., Situmorang, M., \& Tarigan, S. (2018). Innovative Learning Material with Project to Improve Students Achievement on the Teaching of Acid-Base Equilibrium. January. https://doi.org/10.2991/aisteel18.2018 .93

[21] Somnuek, P. (2014). The Development of Teaching and Learning Innovation by Using Instructional Media for Enhancement of Learning Achievement towards Tourism Product Knowledge in Tourism Marketing Class. SHS Web of Conferences, $12, \quad 01040$. https://doi.org/10.1051/shsconf/20141201040

[22] Ratnasari, D., \& Haryanto Haryanto. (2019). Analysis of Utilization of Gadgets as Effective Learning Media in Innovation Education to improve Student Learning Achievement. International Conference on Meaningful Education, KnE Social Sciences, 2019, 460-467. https://doi.org/10.18502/kss.v3i17.4671 